\title{
Uang tutup babah as a customary dispute resolution in gayonese community
}

\author{
Shira Thani* and Alvi Syahrin \\ Doctoral Program in Law, Graduate School, Universitas Sumatera Utara, Medan, Indonesia
}

\begin{abstract}
There are several customary sanctions which are often imposed in customary dispute resolutions in Gayonese community. One of them is uang tutup babah (hush money). It is a payment to resolve customary dispute between parties. However, it is not yet regulated in laws and regulations related to customary law. This paper will discuss the legal strength of decision of uang tutup babah in a customary dispute resolution and its impact. Theory of sociological jurisprudence, theory of harmonization and theory of criminalization were used in this study. In general, uang tutup babah means hush money. It is a customary dispute resolution in some customary communities in Gayo. Although the sanction, uang tutup babah, it is not yet regulated by law on customary institutions, it is often used by parties involved in the dispute to resolve their problem because it has a positive impact on communities. It is also believed that it gives a deterrent effect to the perpetrator. Since this has been done repeatedly and community accept it as a sanction, it should be included in the law to ensure that it gives legal certainty and has legal strength.
\end{abstract}

\section{Introduction}

According to Ter Haar, customary law community is a group of community which has a regular community entity, lives in a certain area, has authorities as well as tangible and intangible wealth in which members of each entity has a normal life in community in accordance with law of nature and none of them has a will or a tendency to escape from the bond or leave it forever. [1]

According to Hazairin, customary law community is a community entity which has equipments to stand on its own feet i.e. having legal entity, authority entity and environmental entity based on a collective right to land and water for all of its members. [2]

The local customary law regulates human behavior to ensure that one's behavior will not harm others. Sadly, although the customary law is so good, it is still very often violated by community which, of course, is harmful to others. Therefore, they try to solve their problems by establishing a customary law institution which is subject to local customary law and has authority to regulate and resolve dispute. It also contains sanctions that can be imposed on the law breaker.

\footnotetext{
* Corresponding Author: shirathani21@yahoo.com
} 
Penal mediation is one of forms of alternative dispute resolutions outside the court or appropriate dispute resolution. In general, alternative dispute resolution is used to resolve civil cases and not criminal cases. According to the applicable laws in Indonesia (positive laws), in principle, a criminal case cannot be resolved outside the court, although in certain cases, it is possible to resolve it outside the court. [3]

Some people in Central Aceh District prefer to resolve their criminal case through a customary institution in which the case is settled by a customary institution called "Sarak opat". Under Point f, Article 1 of Qanun of Central Aceh District Number 10 Year 2002 on Gayonese Customary Law, sarak opat is a Gayonese customary institution consisting of Reje, Imem, Petue and Rayat Genap Mufakat. Although they know that there is a formal court which can settle the case, some community members prefer to resolve criminal case through sarak opat.

Crimes in Gayonese customary law can be divided into four categories, namely: Maas, Rujok, Died and Bela. [4] The imposition of the sanction, among others, aims to recover balancewhich has been affected by the committed offense and create peace and harmony in society, not to decide win or lose. There are several customary sanctions which are often imposed in customary dispute resolutionsin customary court. One of them is uang tutup babah (hush money). It is a payment to resolve customary dispute between parties. Although the sanction is not regulated in Qanun on Gayonese Customary Law, it is often imposed.

Based on situation above, the problems are: How is the legal strength of decision of uang tutup babah in a customary dispute resolution? and what is the impact of the decision of uang tutup babah in a customary dispute resolution on community?

\section{Research Method}

This dissertation research is a juridical empirical research. A sociological-legal approach was applied in the research. Primary and secondary data was collected in this research. The research was conducted in six sub-districts in Central Aceh District. The primary data was collected through an in-depth interview with the research respondents and informants. Meanwhile, the secondary data was collected througha documentary study. Then, the collected data was analyzed by using a qualitative method.

\section{Discussion}

\subsection{Concept and Basis of Customary Law}

Ter Haar gives the definition of customary law based on his theory,Beslissingen Leer. It is the overall regulations which transform into the decisions of law funtionaries (in a broad meaning) that have authority (macht) and influence (invloed) and in its implementation, it is spontaneous and is obeyed sincerely.[5]

According to Bushar Muhammad, customary law is a law which regulates public order and tranquility in achieving peace and calm which does not harm other party. [6]

According to Sobhi Mahmassani, a customary law will only be recognized as a customary law if it meets the following requirements: 1) It must be accepted by good character and logic. 2) It must happen repeatedly and is spread widely. 3) It is still applicable in muamalat, such as in shopping by using a currency in a state where it is still valid. 4) There is no difference in requirements resulting from implicit requirement, and 5) It may not against provisions in nash or fiqh. [7] 
Customary law has the following characteristics: 1) It has a sense of togetherness or a strong communal bond, meaning that human, according to customary law, is a creature which has a strong communal bond; the sense of togetherness embraces all fields of customary law. 2) It has a religious or magic character which is related to way of life in Indonesia. 3) It is encompassed by concrete mind, meaning that it the many and repeatation of concrete life relation, and 4) it is visual, meaning that legal relation will only be established by a visible bond. [8]

According to our law scholars, the sources ofcustomary laws in Indonesia are habits and customs which are based on people's tradition which is handed down from generation to generation and is obeyed and followed by community as a good habit and is useful to manage communal life. These sources can be seen from their habits such as 1) implicit and explicit customary sayings, 2) customary jurisprudence (judge's decisions in resolving customary disputes, 3) documents containing customary provisions such as certificates and regulations, 4) law books or documents issued by the king, and 5) research reports on customary laws. [9]

There are some legal sources of customary institutions in Aceh such as Paragraph (2), Article 18B of the 1945 Constitution, Law Number 44 Year 1999 on the Implementation of Speciality of Special Province of Aceh, Paragraph (1) Article 98 of Law Number 11 Year 2006 on Aceh Governance, Aceh Qanun Number 9 Year 2008 on Guidance for Indigeneous Life and Customs, Aceh Qanun Number 10 Year 2008 on Customary Institution and Qanun of Central Aceh District Number 10 Year 2002 on Gayonese Customary Law.

\subsection{Criminal Sanction in Gayonese Customary Law}

Chapter VI, Article 13, Paragraph (1) of Aceh Qanun Number 9 Year 2008 on the Development of Indigenous Life and Customs clearly lists forms of disputes that can be resolved by a customary institution such as 1) domestic dispute, 2) family conflict related to faraidh, 3) communal dispute, 4) khalwat meusum, 5) property right dispute, 6) theft in family (petty theft), 7) sehareukat property dispute, 8) petty theft, 9) cattle theft, 10) violations of customs on cattle, agriculture and forest, 11) conflicts in sea, 12) conflicts in market, 13) non-serious physical abuse, 14) forest fire (in a small scale which harms customary community), 15) Sexual harrassment, libel, incitement and slander, 16) environmental damage (a small scale), 17) threat (depending on the threat) and 18) other disputes related to norms and customs.

Crimes in Gayonese customary law can be categorized into four categories, namely: maas, rujok, died and bela. Maas is a form of sanction for a non-serious crime which can be settled only by sitting together and forgiving each other. Apolozing is perceived as a sanction because generally it is hard for someone toadmit that he or she is guilty. This is particularly true when it must be done in front of customary leaders. Rujok means to reunite or return. This sanction is more severe than maas because the crime cannot be settled only by sitting and chewing betel nuts together. The perpetrator must provide foods for peusyejuk or kenduri. Died is a fine imposed on someone or some people who are found guiltyof physically abusingother people. If the victim gets a wound from waist below, the perpetrator will be finedsome chicken. If the victim gets a wound from waist to neck, the perpetrator will be fined a goat. However, if the victim gets a wound from neck to head, the perpetrator will be fined a buffalo or a cow. Bela is a punishment which is equal to the result of the criminal act. According to customary law, "mate berbela, rusak berpeniri" or "rusak bersalin, rayohberpeniri". It means that if someone kills other people, the punishment is bela or qishash (beheading) and if the victim gets a wound, he or she will be given a pair of clothes. [4] 


\subsection{Legal Strength of Uang Tutup Babah as a Customary Dispute Resolution and Its Impact on Customary Community}

Any crime which occursin a village is usually reported to village government officials. How it will be resolved greatly depends on its seriousness. Usually, it is only a non-serious crime which can be resolved at village level. The seriousness of the crime also greatly depends on the situation, not on indicators set in the criminal code.

Sarak opat, as an institution which is responsible for the implementation or enforcement of customary law, also functions as a controlling body for public order and security. It deals with social issues and serves as a mediatorin dispute resolution within community. [10] Any problem within Gayonese community will be solved by village government officials known as sarak opat. [11]

Since community has developed, they cannot be bound by village governanceanymore. This, of course, has affected the improvement of public services in rural areasbecause a village cannot be separated from another. Therefore, Central Aceh District Government has established customary institution, sarak opat, at district, sub-district and village/kelurahan levels. [12]

Currently, physical or corporal punishment is rarely or never given in the implementation of customary law. The customary sanction usually only takes the form of an isolation. However, if the perpetrator still behaves badly although he or she has been given advice, community will report him or her to police. However, community usually prefer to handle their case outside the court. Village government officials usually do not give community an opportunity to directly report the case to police because if they directly reports it to policebefore reporting it to their village head, this will make them feel ashamed.

Gayonese community often use customary sanction known as uang tutup babah to solve their problems. Research conducted in some villages found that there were two meanings of uang tutup babahin community: general and specific meanings.Generally, uang tutup babah means hush money. [13] It is given to someone unofficially to ensure that information about his or her problem will not spread widely to public. The problem is solved through the provision of an amount of money or a number of goods. However, if village government officials, in fact, know the problem, they will not investigate it because the problem has been solved and the case is closed. [14]Specifically, uang tutup babah meanscustomary court in which the provision of moneyis considered as a fine imposed on the perpetrator. The payment is done through customary court. According to a government official from Simpang Tiga Uning Village, uang tutup babah is given by someone who has made a mistake in his or her village. The punishment is given to the perpetrator through a customary court. After that, the perpetrator also has to apologize in front of public. [15]

Customary court decision is a result of discussion to resolve a dispute between two parties. It may take the form of a customary sanction, starting from a light one to a severe one. The two parties must voluntarily agree the customary decision and the punishment.

There are some forms of customary punishments or sanctions in customary community such as advise, warning, apology in front of public, compensation, eviction from the village, customary title deprivation, boycott and isolation from community. [16]

Actually, uang tutup babah is not a customary sanction within Gayonese community. It is only one of ways for dispute resolutions. It has a same deterrent effect like customary court or formal court. So, it is hoped that after the imposition of the punishment on someone for his or her unlawful act, others will not do the same act although some still do that.It depends on themselves whether or not they will do the same act.

According to a government official from Mendale Village, dispute resolution through the provision of uang tutup babah usually only involves parties. Village government officials usually only act as a mediator and they are not involved in customary court. The 
problem usually can be solved based on the agreed solution. So, although Reje Kampung knows the problem, he or she will not interfere it because he or she thinks that the problem has been solved by the parties and there is no need to discuss it again. [17]

It is hoped that through the imposition of the sanction or the punishment, the perpetrator will not reoffend and others will not do the same criminal act.Uang tutup babah also gives a deterrent effect to the perpetrator although the effect varies from one perpetrator to another. According to a government official from Bewang Village, uang tutup babah actually can give a deterrent effect because it may cause shame or disgrace on the perpetrator. They will inform the crime to the perpetrator's parents or family. If necessary, they can inform it to his or her Reje Kampung. This is a form of social saction. This, of course, has a positive impact on community. Unfortunately, the imposition of the sanction, uang tutup babah, does not have any legal strength because it is not regulated in Qanun on Gayonese Customary Law. Parties can file a lawsuit against this anytime they want although up to now there is no party which has an objection to this saction, uang tutup babah. [18]

Therefore, uang tutup babah can be included as a sanction in customary law because an act can be recognized as a customary law when it can be accepted by community, is done repeatedly and is spread widely. [7]

\section{Conclusions}

In general, uang tutup babahmeans hush money. It is a customary dispute resolution in some customary communities in Gayo.Although the sanction, uang tutup babah, it is not yet regulated by Qanun on Gayonese Customary Law, it is often used by parties involved in the dispute to resolve their problem because it has a positive impact on communities. It is also believed that it gives a deterrent effect to the perpetrator because he or shesometimes has to spend much money to pay customary leaders or those who have been involved in solving the problem. Since it has been done repeatedly and community accept it as a sanction, it should be included in the law to ensure that it gives legal certainty and has legal strength.

\section{References}

1. B. Muhammad, Asas-Asas Hukum Adat (Pradnya Pramita, Jakarta, 1975)

2. Hazairin, Tujuh Serangkai Tentang Hukum (Jakarta, 1974)

3. B. N. Arief, Mediasi Penal, Penyelesaian Perkara diluar Pengadilan (Pustaka Magister, Semarang, 2010)

4. M. Din, Stimulasi Pembangunan Hukum Pidana Nasional Dari Aceh Untuk Indonesia (UNPAD Press, Bandung, 2009)

5. T. Haar, Asas dan Susunan Hukum Adat (Pradya Paramita, Jakarta, 1974.)

6. B. Muhammad, Asas-Asas Hukum Adat (Pradnya Pramita, Jakarta,1975)

7. S. Mahmassani, Filsafat Hukum dalam Islam (Al-Ma'ruf, Bandung, 1997)

8. S. Wignjodipuro, Pengantar dan Azas-Azas Hukum Adat (Penerbit Alumni, Bandung, 1973)

9. Bisri, Sistem Hukum Indonesia: Prinsip-Prinsip dan Implementasi Hukum di Indonesia (Rajawali Perss, Jakarta, 2010)

10. Syukri, Sarakopat (Hijri Pustaka Utama, Jakarta, 2006) 
11. M. Ibrahim and H. A. Pinan, Syariat dan Adat Istiadat Jilid 1 (Yayasan Maqamam Mahmuda, Takengon, 2002)

12. M. Ibrahim and H. A. Pinan, Syariat dan Adat Istiadat Jilid 2 (Yayasan Maqamam Mahmuda, Takengon)

13. Sabirin, Simpang Empat Village Head, Kebayakan Sub-District, Central Aceh District, Interview, on 10 December 2017

14. Ahmad, Pinangan Village Head, Kebayakan Sub-District, Central Aceh District, Interview, on 10 December 2017

15. Sabirin, Simpang Empat Village Head, Kebayakan Sub-District, Central Aceh District, Interview, on 10 December 2017

16. Muhammad, Simpang Tiga UningVillage Head, Linge Sub-District, Central Aceh District, Interview, on 8 December 2017.

17. Supriadi, Tensaren Village Secretary, Bebesen Sub-District, Central Aceh District,Interview on 11 December 2017

18. Afriandi, Bewang Village Secretary, Bintang Sub-District, Central Aceh District. Interview on 12 December 2017 